\title{
THE LITERARY PRODUCTION OF PHILOSOPHY PROFESSORS 16TH- AND 17TH-CENTURY CENTRAL EUROPE: A BRIEF OVERVIEW
}

\author{
JOSEPH S. FREEDMAN
}

The submitted study deals with various types of works written by 16 th- and 17 th-century Central European philosophy professors. Their intensive production is examined with the use of the following nine categories: 1. lectures, 2. disputations, 3. academic exercises, 4. polemical writings, 5. translations, 6. editions of ancient and post-ancient writings, 7. monographs, including commentaries, 8. auxiliary writings, and 9. other kinds of writings. These categories form the basis of further content analysis.

Keywords: academic exercises - axioms, commonplaces - commentaries - disputations - editions - encyclopedias - lectures - lexicons - pedagogy - textbooks - translations

DOI: $10.14712 / 23365730.2020 .27$

When discussing the literary production of philosophy professors (with a focus on Central Europe) during the 16 th and 17 th centuries, some preliminary comments are warranted. Philosophy is understood here - on the basis of curriculum documents as well as classifications of philosophy and the arts during these same two centuries - to refer largely to (the content of) the following philosophy disciplines: metaphysics, physics, mathematics disciplines, ethics, oeconomica (family life), politics, logic, rhetoric, and grammar, and history. ${ }^{1}$ They

1 Detailed discussion of these classifications and of Central European curricular documents - as well as of the writings of Bartholomew Keckermann (d. 1609) - is provided in the following of my publications: Joseph S. Freedman, Philosophy Instruction within the Institutional Framework of Central European Schools and Universities during the Reformation Era, History of Universities, Oxford 1985, pp. 117-166; IDEM, Cicero in 16th and 17th Century Rhetoric Instruction, Rhetorica 4/3, Summer 1986, pp. 227-254; IDEM, The Diffusion of the Writings of Petrus Ramus in Central Europe, c. 1570-c.1630, Renaissance Quarterly 46/1, Spring 1993, pp. 98-152; IDEM, Aristotle and the Content of Philosophy Instruction at Central European Schools and Universities during the Reformation Era (1500-1650, Proceedings of the American Philosophical Society 137/2, June 1993, pp. 213-253; IDEm, Encyclopedic Philosophical Writings in Central Europe during the High and Late Renaissance (c.1500-c.1700), Archiv für Begriffsgeschichte 37, 1994, pp. 212-256; IDEM, Classifications of Philosophy, the Arts, and the Sciences in Sixteenth-and Seventeenth-Century Europe, The Modern Schoolman 72/1, November 1994, pp. 37-65; IDEM, The Career and Writings of Bartholomew Keckermann (d. 1609), Proceedings of the American Philosophical Society 141/3, September 1997, pp. 305-364. These seven publications have been reprinted - as nos. II, III, IV, V, VI, VII, and VIII, respectively - in: Joseph S. Freedman, Philosophy and the Arts in Central Europe, 1500-1700: Teaching and Texts at European Schools and Universities (Variorum Collected Studies Series CS626), Aldershot 1999. While history is included in the above list, some authors excluded it from philosophy; Keckermann argued that history is not an academic discipline; refer to J. S. Freedman, Classifications, pp. 42 (fn. 38-40), 42, and IDEm, The Career and Writings of Bartholomew Keckermann, pp. 321-322. Here philosophy and the arts will be regarded as synonymous; 
were commonly taught in most Central European academic institutions - here understood to include universities as well as schools where at least some philosophy disciplines were taught - by academic philosophers, who will be considered here as philosophy professors. ${ }^{2}$

The word "literary" is understood broadly to include all writings authored (in whole or in part) by philosophy professors. These writings are placed here - for purposes of the article, with no claims of completeness - into the following categories: 1 . connected with lectures, 2. disputations, 3. connected with academic exercises, including disputations, 4. polemical writings, 5. translations, 6. editions of ancient and post-ancient writings, 7. monograph length publications, some of which can be referred to as commentaries, 8 . what can be referred to as auxiliary writings, and 9 . other kinds of writings, together with issues pertaining to the use of any categories such as those given here. These individual categories are discussed in the order that their numbers are listed.

Writings produced in connection with lectures (1) could focus on specialized philosophical topics, entire philosophy disciplines (with greater or lesser detail, often over a semester or more), or sometimes - mainly in the 17 th century - could have an encyclopedic scope. They are extant in manuscript and published formats and normally have the length of single-volume monographs. Monograph-length writings by philosophy professors are also accorded attention in category 7.

In the case of Roman Catholic and especially Jesuit academic philosophers during the late 16 th and early 17 th centuries, these writings are often extant as manuscripts only. ${ }^{3}$ Writings by Protestant academic philosophers during that same period are normally extant as publications, many of which could be utilized as textbooks. ${ }^{4}$ Such textbooks normally were relatively well organized with [i.] tables of contents and/or [ii.] subject indices and/ or [iii.] section breaks and/or [iv.] marginalia/annotations. ${ }^{5}$

during the course of this period, arts faculties were generally renamed (or: were created) as philosophy faculties at Central European universities.

2 Here it can be noted that at the term Professor was used to refer to teachers at all levels at many Jesuit academic institutions; refer here to Catalogi breves Provinciae Germaniae Superioris omnes qui in Archivio Gen. inveniri possunt ab anno 1556-1709. Catalogi III und eiusdem Provinciae ab anno 1590-1705. Descripsit ex Catalogus in Archivio gen. S.J. P. Herm. Hafner S.J. [München, Jesuiten-Archiv: Abt. 40-3, Nr. 71] Not all of these disciplines were taught throughout this period; refer to J. S. FreEdman, Philosophy Instruction, and Idem, Encyclopedic Philosophical Writings.

3 One such manuscript is Georgii KLAINER Commentarius in reliquos (minores) libros physicos et metaphysicam Aristotelis exce[r]ptus Ingolstadii a Joh. Perzello..., Ingolstadii 1612 [München, Bayerische Staatsbibliothek. (= BSB): Clm 27765]. Among monograph-length philosophy publications by non-Jesuit Catholic authors prior to the mid-17th century are textbooks by Matthaeus Hoen on logic, physics, and metaphysics; the latter two works are cited and briefly discussed in Joseph S. FreEdman, The Godfather of Ontology? Clemens Timpler, All that is Intelligible, Academic Disciplines during the Late 16th and Early 17th Centuries, and Some Possible Ramifications for the Use of Ontology in Our Time, Quaestio, Yearbook on the History of Metaphysics 9, 2009, pp. 3-40 $(8,29)$. Another example, the philosophy lexicons of Georg Reeb SJ, is mentioned here (category 8 and fn. 38).

4 Some manuscripts by Protestant academic philosophers from this period are extant, including: Quaestiones in duos Aristotelis de animae libros dictatae a (Georgio) Lieblero Tubingensis professore... Finis 2di [Secundi] Libri de a[n]i[m]a. Tubingae 1565 2. Novemb[ris]. [Gotha, Forschungsbibliothek: Chart. B 495, fol. 1r-67r].

5 For example, well-organized textbooks on metaphysics, physics, ethics, family life (oeconomica), politics, logic, rhetoric as well as his optics (with an appended treatise on human physiognomy) were published by Clemens Timpler between 1604 and 1617; refer to the discussion and bibliography in Joseph S. FreEDMan, European Academic Philosophy in the Late Sixteenth and Early Seventeenth Centuries: The Life, Significance, and Philosophy of Clemens Timpler, 1563/64-1624 (Studien und Materialien zur Geschichte der Philosophie 
Disputations ${ }^{6}(2)$ are extant largely in published form and very rarely prior to the mid16 th century. ${ }^{7}$ In the 1550 s and 1560 s they were very short publications, often broadsheets, in which questions were posed (with or without answers) and/or theses presented - mainly at Roman Catholic academic institutions; in subsequent decades they, for the most part, increased in length there.${ }^{8}$ At Central European Protestant academic institutions they were rarely published prior to the final decade of the 16th century. But from the early 17 th century onwards they began to be published there in large quantities; some philosophy professors presided over disputations on specific topics so selected and organized that they could be published together as a monograph and possibly as a textbook. ${ }^{9}$

Disputations - especially by Protestants - gained additional significance after the mid17 th century as a medium for the presentation of specialized topics that were not or were rarely discussed in print prior thereto. ${ }^{10}$ Their impact extended beyond the academic institutions where they were published; they sometimes were republished. ${ }^{11}$ The connection between orally presented vis-à-vis published disputations apparently grew more distant in the course of late 16 th and the 17 th centuries. ${ }^{12}$

27), 2 vols., Hildesheim - Zürich - New York 1988. This was somewhat less the case in Central Europe during the middle decades of the 16th century: refer to the brief discussion in J. S. FreEdman, Encyclopedic Philosophical Writings, pp. 219-221.

6 Here the term disputation (disputatio) will be used as synonymous with dissertation (dissertatio). Concerning the distinction between these two terms refer to Hanspeter MARTi Dissertationen, in:Ulrich Rasche (Hg.), Quellen zur frühneuzeitlichen Universitätsgeschichte, Wolfenbütteler Forschungen 128, Wiesbaden 2011, pp. 293-312 (310-311).

7 One exception to this - a disputation published at Leipzig in 1500 - is discussed in Hanspeter MARTI - Reimund B. SDzuj - Robert SeIDEl (eds.), Rhetorik, Poetik und Ästhetik im Bildungssystem des Alten Reiches. Wissenschaftshistorische Erschließung ausgewählter Dissertationen von Universitäten und Gymnasien 1500-1800, Köln - Weimar 2017, reviewed by Joseph S. FreEDMAN, in: Scientia poetica 22, 2018, pp. 299-308. Additional publications pertaining to disputations are cited in Joseph S. FrEEDMAN, Published academic disputations in the context of other information formats used primarily in Central Europe (c. 1550-c.1700), in: Marion GindhartUrsula Kundert (eds.), Disputatio 1200-1800. Form, Funktion und Wirkung eines Leitmediums universitärer Wissenskultur, Trends in Medieval Philology 20, Berlin - New York 2010, pp. 89-128.

8 This evolution from broadsheets to longer published disputations in Ingolstadt is documented in J. S. FREEDMAN, Philosophy Instruction, the Philosophy Concept, and Philosophy Disputations Published at the University of Ingolstadt, c.1550-c.1650, in: Reimund B. Sdzuj - Robert Seidel - Bernd Zegowitz (eds.), Dichtung - Gelehrsamkeit - Disputationskultur. Festschrift für Hanspeter Marti zum 65. Geburtstag, Köln - Wien - Weimar 2012, pp. 316-362. In Dillingen a similar development can be seen on the basis of the extensive presentation and discussion in Ulrich LeINSLe, Dilinganae disputationes. Der Lehrinhalt der gedruckten Disputationen an der Philosophischen Fakultät der Universität Dillingen, 1555-1648, Jesuitica 11, Regensburg 2006, reviewed by J. S. FreEdman, in: Catholic Historical Review 96/3, July 2010, pp. 563-566. During the late 17th century disputations could approach or reach textbook length; for example, Matthias KIRCHOFFER SJ and Wolffgangus EngelBerto ab Auersperg, Orbus lusus, pars prima seu geographicus, Graecii: Typis Francisci Widmanstadii, 1659 [München BSB: Res/4 Geo.u. 61], and a Salzburg disputation titled Manuale philosophicum (1665) cited and discussed in J. S. Freedman, Published academic disputations, pp. 104-105, 127 (J).

9 For example, refer to the disputations on rhetoric published as a volume by Christoph Heidmann in 1617, cited in J. S. Freedman, Cicero in 16th and 17th Century Rhetoric, pp. 229 (fn. 9, no. 6), 230, 244 (Table c, 6). A volume published by Theophilus Ebert in 1620 (which consists of a series of individual disputations on individual philosophy disciplines as well as on theology, jurisprudence, medicine, and the mechanical arts) is cited in J. S. Freedman, Encyclopedic Philosophical Writings, pp. 232 (fn. 63, no. 9), 252 (Table S, no. 9).

10 Refer to the discussion thereof in Joseph S. FreEdman, Introduction. The Period Around 1670. Some Questions to Consider, in: idem (ed.), Die Zeit um 1670: Eine Wende in der europäischen Geschichte und Kultur? (Wolfenbüttler Forschungen 142), Wiesbaden 2016, pp. 7-73 (29-31).

11 See the examples provided in J. S. Freedman, Introduction. The Period Around 1670, p. 30 (fn. 84).

12 Some comments pertaining to oral disputations are given in J. S. FreEdman, Published academic disputations, pp. 94-95, 109-111, 120-121, and IDEM, in: Scientia poetica 22, 2018, pp. 300 (fn. 4), 305 (fn. 18). 
Published disputations were normally either held [i.] in connection with academic degrees or [ii.] for practice purposes. For the latter (and often for the former) there usually was a presider (often a professor) and one or more (normally student) respondents. The question of who was the author of disputations has been often discussed; however, it is generally not possible to provide a definitive answer to that question. ${ }^{13}$

Writings connected with academic exercises (3) include treatises or segments of treatises that provide guides to the holding of oral disputations. ${ }^{14}$ In these guides, the duties of the respondent (also referred to as the defendent or proponent) and of the opponent are discussed. Sometimes included is discussion of a presider and his duties. But noteworthy is the fact that the opponent(s) in oral disputations are almost never mentioned within disputations published prior to the 18th century. ${ }^{15}$

Academic exercises also included style exercises (sometimes referred to as exercitatio styli), letter writing (epistolica), memorization, pronunciation, and declamations (preliminary to orations), translations, and repetitions. ${ }^{16}$ Some separate publications devoted to letter writing, memory, orations, and style are extant. ${ }^{17}$ Academic exercises were also discussed in publications having a broader scope..$^{18}$

While likely less prevalent than by theologians, polemical writings (4) published during this period by philosophy professors are extant. Some examples can be given here. In a disputation published in 1610, Jacob Martini and Johann Donner attacked a textbook on logic by Bartholomaeus Keckermann; this was followed by a treatise published in 1611 by Adam

13 See the discussion in J. S. Freedman, Published academic disputations, pp. 109-111; H. Marti - R. B. SDzujR. Seidel (eds.), Rhetorik, Poetik und Ästhetik, p. 171, and J. S. Freedman, in: Scientia poetica 22, 2018, pp. 300 (fn. 7), 306 (fn. 20).

14 Refer to the discussion on the holding of oral disputations by Aegidius Hunnius (1552) in J. S. FREEDMAN, Published academic disputations, pp. 94-95, 120 (Table 9).

15 To my knowledge, the earliest published disputation in which opponents are named appeared in 1614; that disputation and all others known to me published up to 1700 in which opponents are named are cited in J. S. Freedman, Published academic disputations, pp. 95-96, 102-103, 125 (Table F).

16 Refer to the lists of academic exercises at six academic institutions between 1551 and 1688 as presented in J. S. Freedman, Published academic disputations, pp. 91-92, 115-119 (Tables 3 through 8).

17 Orationum ex latinis historiographis selectarum syntagma, eloquentiae amatoribus utilissimum, Coloniae: Sumptibus Bernardi Gualtherij, 1605 [Harvard University, Widener Library: KC 16045]. This treatise on orations was republished in 1623, 1645, and 1662. Joan(nes) Henricus Alstedius, System mnemonicum duplex, Prostat in nobilis Francofurti Paltheniana, 1610 [München BSB: Paed.th. 74]. Examples of treatises on letter writing, and style are cited in J. S. Freedman, Cicero in 16th and 17th Century Rhetoric, pp. 230-231, and in IDEM, Published academic disputations, pp. 97-98, 122 (Table 11).

18 Refer to the discussion of memory, pronunciation and repetition in Johannes Henricus AlstedIUs, Consiliarius academicus: id est methodus formandorum studiorum... editio secunda passim limata \& aucta, Argentorati: Sumptibus haeredum Lazari Zetzneri, 1627, pp. 46-47 [Wolfenbüttel, Herzog August Bibliothek, M: Pc 4]. This work was originally published in 1610. Memory and pronunciation are discussed in most of the treatises on rhetoric cited and mentioned in J. S. Freedman, Cicero in 16th and 17th Century Rhetoric, pp. 233-235, 247-249. Collections of materials that could be used for academic exercises in grammar and/or rhetoric were sometimes referred to as Progymnasmata (for example): Jacobus Pontanus, Progymnasmatum latinitatis... volumen primum... Ad usum scholarum humaniorum Societatis Jesu, Ingolstadii: Excudebat David Sartorius, 1588 [München BSB: L.ldt. 635-1], and Antonius Burchardus, Progymnasmatum eloquentiae partes tres, Stetini: Typis Kelnarianis impensis Johannis Echornij, 1612 [Augsburg, Staats- und Stadtbibliothek: 4 Phil 51]. Academic exercises are discussed in Bohuslaus Aloysius BALBINus SJ, Verisimilia humaniorum disciplinarum, Pragae: Typis universitatis Carolino Ferdinandea in Collegio Soc: Jesu ad S. Clementem, 1666 [München BSB: L.eleg.g. 21]. It was republished in 1687, 1701, and 1710. 
Rassius in rebuttal of that attack, to which Donner responded with a treatise, also published in 1611, in which he attacked Rassius's defense of Keckermann's textbook on logic. ${ }^{19}$ Portions of some 17th-century publications contained polemical criticisms of All that is Intelligible (omne intelligibile) and other concepts as discussed by Clemens Timpler. ${ }^{20}$ And some late 16th- and early 17 th-century publications were devoted - in whole or in part - to polemics against and also in defense of Petrus Ramus. ${ }^{21}$

Translations (5) by philosophy professors included translations of Aristotle's writings from Greek into Latin. Individual translations of these writings could vary considerably in content. $^{22}$ They could also sometimes result in controversy: one such example is a translation of Aristotle's ethics published by Victorin Strigel in Leipzig in the year 1572; this translation is defended in a preface thereto (dated in 1571) by Jakob Monau. ${ }^{23}$

Editions (6) of ancient and post-ancient authors were published during this period, many of which were edited by philosophy professors. ${ }^{24}$ With regard to ancient authors, editions of writings by Aristotle and Cicero were the most common. ${ }^{25}$ Greek language, Latin language, and Greek-Latin editions of Aristotle's writings were published in the 16th and early 17th centuries, but apparently with decreasing frequency thereafter. Also published were some editions of post-medieval philosophers. For example, in 1594 Rudolph Goclenius published an edition of writings by twelve 16th century authors on the subject-matter of psychology. ${ }^{26}$ And in 1613 Johann Heinrich Alsted published a two-volume posthumous edition of writings by Bartholomaeus Keckermann. ${ }^{27}$

19 These three publications are cited in J. S. FreEdman, The Career and Writings of Bartholomew Keckermann, p. 350.

20 J. S. Freedman, European Academic Philosophy, pp. 244-246, 626-627.

21 For example: (Jodocus Convinus), Tetraemerum .. pro defensione sententiae Andreae Libavii, de apodixi Aristotelea contra mentem Petri Rami, adversus insana sophismata \& virulentissimas calumnias Joannis Bisterfeldii ..., Francofurti: Excudebat Ioannes Saurius, impensis Petri Kopffij, 1596, (and) Johannes BisterfELDUs: Nex \& anatomia horridi ... et infirmi apodictici monstri, a personato isto et perforato Libavio nuper abiecti, Hanoviae: Apud Guilielmum Antonium, 1597 [Basel, Universitätsbibliothek: K.f.V 36 (2 and 3)].

22 This is even suggested by the Latin term (interpretatio) for translation. Two examples of close ties between translation and commentary (as well as the example of a publication in which differences within two translations of Aristotle are explained) are mentioned in J. S. FreEdman, Aristotle and the Content of Philosophy, pp. 226 (fn. 53, 3c, 4b, 5), 228, 248 (Table S, $\alpha, 3 \mathrm{c}, 4 \mathrm{~b}, 5$ ).

23 Refer to the discussion thereof in J. S. FreEdman, The 'Melanchthonian Encyclopedia' (1597) of Gregor Richter (1560-1624), Fragmenta Melanchthoniana 3, Ubstadt - Heidelberg - Basel 2007, pp. 105-141 (114-115).

24 For example, the following four volume edition was published by Caelius Secundus Curio, a professor at the University of Basel: Aristotelis Stagiritae tripartitiae philosophiae opera omnia, Basileae: Per Joannem Hervagium, 1563 [München BSB: 2 A.gr.b.93-1/4].

25 Refer to the following: F. Edward Cranz, Bibliography of Aristotle Editions, 1501-1600, Bibliotheca bibliographia Aureliana 38, Baden-Baden 1971. Some editions of Cicero's writings on rhetoric are cited in J. S. Freedman, Cicero in 16th and 17th Century Rhetoric, pp. 229-230, 245-246 (Table c, 1a, 1b, 4).

26 Rudolph GoclenIUs (ed.), ЧҮХОАОГІА: hoc est, de hominis perfectione, animo... Marpurgi: Ex officina typographica Pauli Egenolphi, 1594 [München BSB: Ph.sp. 316]. Also refer to an edition of the dialectic of Petrus Ramus (collated with the writings of seven 16th-century authors and collected by Christoph Cramer) published by Goclenius in 1600, cited in J. S. FreEdman, The Diffusion of the Writings of Petrus Ramus, pp. 120, 128 (8a).

27 This is cited in J. S. Freedman, The Career and Writings of Bartholomew Keckermann, p. 346 (A. 36 and A. 39); an edition of Keckermann's mathematics writings cited there (p. 346, A. 39) was published in 1617 and again in 1621 and 1661 . 
Also extant are writings (in published and manuscript formats) that can be referred to as commentaries on ancient ${ }^{28}$ and post-ancient authors (7). It is not clear how to accurately describe what a "commentary" on the writings of an ancient or post-ancient author is. Here the example of Renaissance Aristotle Commentaries in manuscript and published formats between c. 1500 and c. 1650 can be discussed.

In the first published installment of his bibliography on Renaissance Aristotle Commentaries, Charles Lohr presents what he refers to as 12 different categories thereof. ${ }^{29}$ Some of these individual categories are equated by him with the use of multiple Latin-language terms. However, many of these writings could best be described as independent monographs, and many of them could also be regarded as textbooks. Some of them nonetheless contain many citations of Aristotle while other writings referred to as Aristotle commentaries on their title pages in fact rarely mention Aristotle within their texts. ${ }^{30}$

What can be regarded is as a significant general group of writings by philosophy professors are referred to here as auxiliary writings (8), which could be frequently utilized for the preparation of other writings. ${ }^{31}$ These included: a) collections of axioms / commonplaces, ${ }^{32} \mathrm{~b}$ ) encyclopedias, c) lexicons, and d) other writings that provided useful information for philosophy professors but that were not necessarily directly used in instruction.

Many collections of axioms/commonplaces were taken - in whole or in part - from the writings of Aristotle, and/or Cicero, and/or Plato. ${ }^{33}$ Others were writings on specific arts/ philosophy subject matters. Among such writings are collections of axioms on family life (oeconomica), politics, and history published by Gregor Richter. ${ }^{34}$ Encyclopedias were rarely published during most of the 16 th century but more often in the 17 th. ${ }^{35}$ Encyclope-

28 Note the following three Plato commentaries by Sebastián Fox Morcillo (Sebastianus Foxius Morzillus), In Platonis Timaeum Commentarii, Basileae: Per Johannem Oporinum, (1554 Mense Augusto) [München BSB: 2 A.gr.b. 869]; In Platonis dialogum, qui Phaedo, seu de animorum immortalitate inscribitur, Basileae: Per Joannem Oporinum (1556 Mense Martio) [München BSB: 2.A.gr.b.309\#Beibd.1]; Commentatio in decem Platonis libros de republica, Basileae: Ex officina Joannis Oporini, (1556 Mense Septembri) [München BSB: 2.A.gr.b. 867].

29 Charles LoHR, Renaissance Latin Aristotle Commentaries: Authors A-B, Studies in the Renaissance 21, 1974, pp. 228-289 (230-232). The remaining installments thereof were published in Renaissance Quarterly in 1975, $1976,1977,1978,1979,1980$, and 1982.

30 Refer to the discussion thereof in J. S. Freedman, European Academic Philosophy, pp. 179-180, 586-587.

31 For additional examples of auxiliary writings beyond those discussed here see Gilbert Hess, Enzyklopädien und Florilegien im 16. und 17. Jahrhundert. Doctrina, Eruditio und Sapientia in verschiedenen Thesaurierungsformen, in: Theo Stammen - Wolfgang E. J. Weber, Wissenssicherung, Wissensordnung und Wissensverarbeitung: das europäische Modell der Enzyklopädien, Colloquia Augustana 18, Berlin 2004, pp. 39-57.

32 Concerning commonplaces see Ann Moss, Printed Commonplace-Books and the Structuring of Renaissance Thought, Oxford 1996, reviewed by J. S. FreEDMAn, in Scientia Poetica 2, 1998, pp. 222-242.

33 Auctoritates Aristotelis, Problemata Aristotelis, Aristotelis... sententiae, Aristotelis florum... , Axiomata philosophica Venerabilis Bedae, were among the many titles of such collections; refer to the examples cited in J. S. Freedman, Aristotle and the Content of Philosophy, pp. 226-247 (Table 5, $\alpha, 1 \mathrm{a}, 1 \mathrm{~b}, 1 \mathrm{c}, 1 \mathrm{e}, 1 \mathrm{f})$. Concerning Problemata refer to John Monfasani, The Pseudo-Aristotelian Problemata and Aristotle's De Animalibus in the Renaissance, in: Anthony Grafton - Nancy Siraisi (eds.), Natural Particulars: Nature and the Disciplines in Renaissance Europe, Cambridge, Mass. 1999, pp. 205-247.

34 These collections of axioms are cited in J. S. FreEDMAn, The 'Melanchthonian Encyclopedia', pp. 133-134.

35 Refer to the extensive discussion and citations in J. S. FreEDMAn, Encyclopedic Philosophical Writings. One exception to this - discussed there on pp. 220, 241 (Table E, 12), 244-245 (Table K) - is the encyclopedic philosophical digest (digestio) by Hieronymus GürTLER VON WILDENBERG (1464/5-1558), Totius philosophicae humanae in tres partes, rationalem, naturalem, \& moralem, digestio, Basileae: Per Johannem Oporinum, (1555 Mense Augusto), pp. 344-376 [München BSB: Ph.u.551]. 
dias used by academic philosophers could be limited to the subject-matter of philosophy itself or could have a broader focus than just philosophy (and could include jurisprudence, medicine, theology, mechanical arts, etc. $)^{36}$

Philosophy lexicons appear to have been very scarse in the 16 th century ${ }^{37}$ but less so during the 17th century. Lengthy philosophy lexicons included two by Rudolph Goclenius (1613 and 1615) and one by Johannes Micraelius (1653, 1661, and 1662). Shorter lexicons were published by Georg Reeb SJ ${ }^{38}(1629,1631,1636,1637,1642,1650,1653,1682$, and after 1700); they were incorporated, together with shorter philosophical lexicons by Jean Thierry $\left(1644,1654,1662,1664\right.$, and after 1700) and Henricus Castenaeus ${ }^{39}(1612,1614$, $1616,1617,1623,1658)$, within an encyclopedic compendium by Johann Adam Scherzer $(1654,1658,1675,1686,1704) .{ }^{40}$

Included among other auxiliary writings are some publications by Johann Heinrich Alsted. His Consiliarius philosophicus is essentially a study guide (in table format). ${ }^{41}$ His Panacea philosophica is a teaching guide. ${ }^{42}$ And Alsted's Philosophia digne restituta focuses on what he regards as the conceptual foundations of philosophy. ${ }^{43}$ Pedagogical writings by other philosophy professors were also published. ${ }^{44}$

Writings by philosophy professors also included some (9) that do not fall within the eight categories given here. Some of their writings pertained to their academic duties. These could include orations written in connection with the awarding of academic degrees; Philosophy professors sometimes wrote an oration at the funeral of a colleague. ${ }^{45}$ They also

36 Johann Heinrich Alsted’s Cursus philosophicus encyclopaedia (1620) focuses on philosophy while his Encyclopaedia septem tomis distincta (1630) has a much broader focus. Gregor Richter's 'Melanchthonian Encyclopedia' [see J. S. FreEdman, The 'Melanchthonian Encyclopedia '] includes subject matter from theology and literature (Greek and Latin) as well as from philosophy.

37 A short dictionary on moral philosophy is included in Wildenberg [fn. 35], pp. 344-376.

38 The lexicons published by Georg Reeb originated in two short disputations published at the University of Dillingen in 1624 and 1625; refer to the discussion of him and of these two disputations in Ulrich LEINSLE, Dilingane disputationes, p. 671 (Index).

39 Most editions of his lexicon included content from theology as well as from philosophy. The first edition of his Celebriorum distinctionum tum philosophicarum tum theologicarum synopsis (1612) is cited in J. S. FREEDMAN, Classifications, p. 63.

40 With regard to Scherzer and the contents of his Vade Mecum see Stephan MeIER-Oeser (ed. and introd.), Johann Adam Scherzer. Vade mecum sive Manuale Philosophicum. Neudruck der Ausgabe Leipzig 1675, Stuttgart-Bad Cannstatt 1996.

41 Alsted, Consiliarius Philosophicus.

42 Refer to the citation and discussion of the Panacea Philosophica (1610) in: J. S. Freedman, Encyclopedic Philosophical Writings, pp. 232, 251-252 (Table R).

43 Joseph S. Freedman, Johann Heinrich Alsteds ,Philosophia digne restituta' (1612). Ein kurzer Überblick über Inhalt und Bedeutung des Werkes, Nassauische Annalen 123, Wiesbaden 2012, pp. 161-181.

44 For example: Johannes Rhenius (ed.), Methodus institutionis nova quadruplex 1. M. Johannis Rhenij 2. Nicodemi Frischlini 3. Ratichij \& Ratichianorum ter gemina 4. Jesuitarum, vulgo Janua linguarum dicta, Lipsiae: Typis haeredum Valentini am Ende, 1617 [Augsburg, Staats- und Stadtbibliothek: Bild 1618].

45 Clemens Timpler published an Oratio de Opinione (1595) held at a ceremony awarding 9 University of Heidelberg students B.A. degrees; his funeral oration for Hermann Hausmann, the principal of the lower level of the Steinfurt Gymnasium illustre, was held and published in 1606; see J. S. Freedman, European Academic Philosophy, pp. 741 (7), 760 (24). He also wrote (p. 770) letters of recommendation for Johann Rudolf Lavater (1 May 1601) and Jodocus Wagner (1 September 1609) as well as entries in student albums for Lavater (1 May 1600) and for Friedrich Kemner (15 April 1602). Orations could also be published apart from direct academic duties; refer to the citation and discussion of two orations published by Nicolaus Andreas Granius (1612) in J. S. Freedman, The Godfather of Ontology? Clemens Timpler, pp. 20-21, 38 (Table K, $\beta$ ). 
sometimes prepared curriculum documents. ${ }^{46}$ Correspondence by some individual philosophy professors is extant. ${ }^{47}$ Some academic philosophers also published dramatic works. ${ }^{48}$ And other genres of such writings might be added as well. ${ }^{49}$

There are some potential issues with these nine categories. First, the volume of these writings by philosophy professors is enormous. Many are no longer extant. These extant writings are accessible to some greater or lesser extent. But even the number of those that are easily accessible is very large. These or any such categories will be based by necessity on the use of a limited portion of those sources.

Second, what is meant by some of the individual categories presented here - for example, Aristotle commentaries, disputations, and encyclopedias - may not be clear. ${ }^{50}$ Diverse views concerning what these categories do or should include can influence how they are selected and named. It would be difficult to maintain that some individual ways of selecting and naming categories are clearly either "right" or "wrong".

Third, these categories are not mutually exclusive. For example, an Aristotle edition could contain a wide range of other content. ${ }^{51}$ Disputations could contain correspondence

46 See curriculum plans by Jacobus Micyllus at the University of Heidelberg: Constitutiones ac leges Collegii Facultatis artium... 1551 [Heidelberg, Universitätsarchiv: I, 10, Nr. 18, 54r-68r] and by Arnoldus BurenIUS for the University of Rostock Arts Faculty in 1566 as cited in J. S. FreEDMAn, Philosophy Instruction, p. 160; school curriculum plans by professors are also cited there (pp. 152, 154, 156, 158-161).

47 One example is correspondence by Bartholomew Keckermann in which his political commentary of (then-) current events complemented his publications on politics; see the discussion in J. S. FrEEDMAN, The Career and Writings of Bartholomew Keckermann, pp. 320-321. Clemens Timpler's correspondence is cited in J. S. FrEEDMAN, European Academic Philosophy, pp. 768-770.

48 Concerning dramatic works written at Magdeburg Gymnasium see Carsten NAHRENDORF, Humanismus in Magdeburg. Das Altstädtische Gymnasium von seiner Gründung bis zur Zerstörung der Stadt (1524-1631), Frühe Neuzeit 193, Berlin - München - Boston 2015, pp. 342-393. While a philosophy professor at the University of Dillingen, Georg STENGEL wrote and produced the following dramatic works: Otto Redivus, Summarischer Inhalt der Comeodi... Gehalten in ermelter Universitet zu Dillingen / den 22. Octoberis 1614, Gedruckt zu Dilingen bey Johannes Mayer [München BSB: Res/4 Bavar. 2197,IV,1/89\#Beibd. 12] and Triumphus Beatae Mariae Virginis (1617) [Dillingen, Studienbibliothek: XV 237b.]. Concerning Georg Stengel and his dramatic works see Martin Mulsow, Stengel, Georg, in: Laetitia Boehm - Winfried Müller - Wolfgang J. Smolka (eds.), Biographisches Lexicon der... Universität München, Teil 1: Ingolstadt-Landshut 1472-1806, Ludovico Maximilianea..., Forschungen 18, Berlin 1998, pp. 417-418.

49 Writings on dialogues are cited in J. S. FreEDman, Encyclopedic Philosophical Writings, pp. 220-221, and IDEM, Published academic disputations, p. 99 (fn. 31). On academic travel, refer to Theod[orus] Zwingerus, Methodus apodemica, Basileae Eusebii Episcopii Opera atque impensa, 1577 [München BSB: ESlg/4 lt. coll. 29], and Alstedius, Consiliarius, pp. 18-33 (pereginatio). While not per se a philosophy professor, Johannes Theill, the Rector of a school in Bautzen (1642-1679), published over 360 programmatic writings, many of which have philosophy content - during his tenure there. Beginning in the year 1649 many of them included the use of footnotes; this is the earliest use thereof that is known to date. Concerning him see Richard NEedon, Die Lectionum praxis des Magisters Johannes Theill, Berlin 1911.

50 The question of what is an Aristotle commentary has been posed here (7). On the basis of sources cited and discussed in J. S. Freedman, Cicero in 16th and 17th Century Rhetoric, pp. 229-231, 245-246 the same question could be posed with regard to Cicero commentaries. With respect to disputation(s) this question is addressed in J. S. Freedman, Published academic disputations, pp. 111-113. What an encyclopedia is can be discussed using J. S. Freedman, Encyclopedic Philosophical Writings, Tables E, K, L, Q, and S (and especially I., II. and III. on pp. 250-251). 16th- and 17th-century discussions of classifications and definitions are discussed in J. S. Freedman, Introduction. The Study of Sixteenth- and Seventeenth-Century Writings on Academic Philosophy: Some Methodological Considerations, in: idem, Philosophy and the Arts, no. 1, pp. 1-40 (2-7).

51 Volume 4 of Aristoteles ... opera omnia [fn. 24] contains an edition of the Problemata Aristotelis (natural philosophy and medicine), sections on sex (res venerea), mathematics (res mathematicae) and the study of 
or a multi-lingual dictionary. ${ }^{52}$ And collections of axioms or disputations as well as shorter encyclopedias could serve as textbooks. ${ }^{53}$

And fourth, categories in general are (to some greater or lesser extent) theoretical. They normally more or less closely approach - what we can refer to as - reality or practice. Yet they can only do so as a limit. Without theory and categories, however, we cannot discuss reality at all. The nine categories created and discussed here are basically used as a vehicle to present and briefly discuss a cross section/overview of the kinds of writings produced by 16 th- and 17th-century Central European philosophy professors; the writings cited and discussed here can only represent a small segment of those writings that were actually produced.

\section{JOSEPH S. FREEDMAN}

\section{LITERÁRNÍ PRODUKCE PROFESORŮ FILOSOFIE VE STŘEDNÍ EVROPĚ 16. A 17. STOLETÍ: KRÁTKÝ PŘEHLED}

\section{RESUMÉ}

Předkládaná studie analyzuje spisy středoevropských profesorů filosofie 16. a 17. století na univerzitách a na dalších školách, na nichž se filosofie vyučovala. Tato díla jsou zkoumána s využitím devíti kategorií: 1. texty spojené s přednáškami, 2. disputace, 3. akademická cvičení (včetně disputací), 4. polemické spisy, 5. překlady, 6. vydání starověkých a postantických spisů, 7. monografie, včetně komentářů, 8. pomocné spisy (včetně sbírek axiomů, encyklopedií, lexikonů a pedagogických pojednání) a 9. jiné druhy spisů, včetně orationes, kurikulárních dokumentů, korespondence a dramatických děl. To, co se myslí některými z těchto kategorií, nemusí být zcela jasně definovatelné a některé z nich se vzájemně překrývají, tj. nevylučují se navzájem. Musí být vytvořeny pouze pomocí části velkého objemu existujících spisů. Takové problémy se obecně týkají použití všech kategorií. Zde slouži jako prostředek k prezentaci prưřezu těchto spisů profesory filosofie.

(český překlad Martin Holý)

Joseph S. Freedman, B.A., M.A., M.I.LS., Ph.D., Professor of History

Alabama State University, Montgomery, Alabama / USA

jfreedman@alasu.edu

joseph-freedman@usa.net

literature (litterarum studia), a short commentary on Aristotle's Mechanics, a short commentary on Aristotle's Physiognomy, and five other short treatises.

52 See the examples given in J. S. FreEdman, Published academic disputations, pp. 103-104, 105-106,108-109, $126(\mathrm{I}), 128(\mathrm{M})$.

53 For example: Johannes Cammerhofius, Encyclopaedia Isagogica, Islebii: Typis Andreae Coqui, 1673 [Halle, Universitäts- und Landesbibliothek: Ung IV A 14 (2)]. 